\title{
Increasing medical burden of child abuse
}

\author{
A SHARMA AND R SUNDERLAND
}

Children's Programme, Springfields, Birmingham

SUMmARY During the decade January 1976 to December 1985, as a result of increased public awareness, the numbers of reported (but not proved) cases of abuse to children living in South Birmingham increased thirtyfold; the incidence of detected and proved cases of abuse increased fourfold. The increase was principally due to bruises, scalds, and neglect. The numbers of serious fractures and brain injuries did not increase. The first case of sexual abuse was reported in 1981 and this was followed by a subsequent rise in the detection rate. The combination of increased reporting, increased incidence of proved abuse, and the necessity for increased supervision of families and intervention has created a serious burden on the child health services that may necessitate a reduction in services to other children. Alternative ways of tackling the problems of child abuse may have to be introduced, but they may have unwelcome consequences.

Violence against infants and children has been recorded throughout history. Darwin postulated that one could correlate the beginning of human civilisation with the recording of infanticide. ${ }^{1}$ The reported incidence of child abuse varies with definition and is thought to be always underestimated. It is generally accepted in Britain that one in 1000 children is severely injured and one in 10000 killed by child abuse each year. ${ }^{2}$

The public started to become aware of the size of the problem after Kempe used the intentionally emotive phrase 'battered baby syndrome' in $1962 .^{3}$ Despite better detection rates and attempted prevention, however, reports of fatal non-accidental injuries from the general public gave the impression that there had been an increase in severe physical abuse that could be correlated with changing social conditions.

Child abuse is often so horrifying that there is a natural public reaction to divert services to investigate, treat, or prevent it. With finite resources this cannot be done without reducing or redeploying other children's health services. A discussion document from the Department of Health and Social Security (DHSS) recommended changes in procedure but suggested that these could be achieved within current staffing and budget limits. ${ }^{4}$ The present study was undertaken to find out if, in one urban health district, there had been an objective change in the range of child abuse and also to see if there had been any changes in the type of medical work load.

\section{Subjects and methods}

All available records were examined of abused children living in the area covered by the South Birmingham Health Authority that had been detected for the period January 1976 to December 1985 . These records were held by community health doctors, health visitors, paediatric wards, the National Society for the Prevention of Cruelty to Children (NSPCC), and the social services. Children first identified in other health districts were included, but residents from outside the area but identified within it were not. Details of the referring source, the child's age, sex, social background, and injuries were abstracted. Incidences are presented as the number of cases per thousand children aged $0-15$ living in the area.

Cases of injuries that were not adequately explained but which were not proved to be abuse, and unsubstantiated reports from the public about possible abuse, were not included. Because of the seriousness of a positive diagnosis for the family, and a missed diagnosis for professionals, all these cases took a considerable time to investigate. The number of cases increased from 15-30 a year in the 1970 s, to 450 in 1986. About half were found to be incorrect or malicious after initial inquiries-for example, a child was anonymously referred as being systematically starved when (after lengthy enquiries) it transpired that the mother's sister was annoyed at not having received a birthday card and 
knew that a referral alleging child abuse would inconvenience the family.

\section{Results}

The numbers of children abused, total numbers at risk, and annual incidences are shown in table 1 . Over the decade there was a fourfold increase in cases of proved abuse. This occurred at a time when the total population of children was falling. During the same period there was an even greater increase

Table 1 Numbers and rates of abused children within South Birmingham Health Authority 1976-85

\begin{tabular}{lllll}
\hline Year & $\begin{array}{l}\text { Child } \\
\text { population }\end{array}$ & $\begin{array}{l}\text { No of } \\
\text { cases of } \\
\text { abuse }\end{array}$ & Rate & $\begin{array}{l}\text { No of } \\
\text { conferences }\end{array}$ \\
\hline 1976 & 59300 & 22 & $0 \cdot 37$ & 29 \\
1977 & 59800 & 22 & $0 \cdot 37$ & 28 \\
1978 & 56000 & 18 & $0 \cdot 32$ & 31 \\
1979 & 54100 & 22 & $0 \cdot 41$ & 52 \\
1980 & 53000 & 27 & $0 \cdot 51$ & 52 \\
1981 & 51414 & 23 & $0 \cdot 45$ & 40 \\
1982 & 51545 & 16 & $0 \cdot 31$ & 28 \\
1983 & 50952 & 25 & $0 \cdot 49$ & 46 \\
1984 & 50457 & 61 & $1 \cdot 21$ & 123 \\
1985 & 50145 & 83 & $1 \cdot 66$ & 154 \\
\hline
\end{tabular}

in the associated medical workload, as indicated indirectly by the increase in the number of case conferences. Each lasted one to two hours in addition to the time taken in preparation and follow up, and was attended by an average of four health authority employees.

Table 2 shows that there has been no major change in the pattern of injury; soft tissue injuries (including bruises and burns) still constitute most of the abuse. The numbers of severe injuries (including fractures and brain damage) have not increased but cases of neglect have increased from two to 22 . The first case of sexual abuse was reported in 1981, and there has been a subsequent rise, though the incidence is still below that reported from other parts of the country. ${ }^{5}$ It is not clear yet whether the actual incidence or the rate of detection is low. There is local anxiety about a perceived failure to achieve some notional national norm. Schools and nurseries have responded to a training programme with an increasing, and increasingly early, rate of detection. Health visitors continue to play a vital part in the detection of the abuse of preschool children.

Table 3 shows the biological and social characteristics of the abused children. Both sexes were equally prone to abuse. In keeping with other

Table 2 Type of injury and source of detection

\begin{tabular}{|c|c|c|c|c|c|c|c|c|c|c|}
\hline & $\begin{array}{l}\text { Year: } \\
1976\end{array}$ & 1977 & 1978 & 1979 & 1980 & 1981 & 1982 & 1983 & 1984 & 1985 \\
\hline \multicolumn{11}{|l|}{ Type of injury: } \\
\hline Soft tissue & 16 & 13 & 11 & 16 & 16 & 13 & 6 & 14 & 33 & 51 \\
\hline Serious & 4 & 3 & 3 & 3 & 1 & 1 & 3 & 3 & 4 & 5 \\
\hline Neglect & 2 & 6 & 4 & 3 & 10 & 8 & 6 & 8 & 20 & 22 \\
\hline Sexual abuse & - & - & - & - & - & 1 & 1 & - & 4 & 5 \\
\hline \multicolumn{11}{|l|}{ Source: } \\
\hline School & 8 & 7 & 9 & 5 & 6 & 8 & 4 & 3 & 22 & 36 \\
\hline Social worker & - & - & - & 1 & 1 & 2 & 1 & 7 & 4 & 7 \\
\hline Health visitor & 3 & 4 & 2 & 5 & 4 & 4 & 4 & 6 & 10 & 11 \\
\hline Hospital & 7 & 5 & 6 & 5 & 8 & 6 & 4 & 4 & 19 & 10 \\
\hline Other & 4 & 6 & 1 & 6 & 8 & 3 & 3 & 5 & 6 & 18 \\
\hline
\end{tabular}

Table 3 Social and biological characteristics of abused children

\begin{tabular}{|c|c|c|c|c|c|c|c|c|c|c|}
\hline & $\begin{array}{l}\text { Year: } \\
1976\end{array}$ & 1977 & 1978 & 1979 & 1980 & 1981 & 1982 & 1983 & 1984 & 1985 \\
\hline Boys & 15 & 10 & 7 & 15 & 13 & 9 & 11 & 13 & 31 & 42 \\
\hline Girls & 7 & 12 & 11 & 7 & 14 & 14 & 5 & 12 & 30 & 41 \\
\hline Age $<4$ years & 9 & 13 & 8 & 14 & 14 & 12 & 9 & 16 & 29 & 28 \\
\hline First child & 13 & 10 & 11 & 14 & 14 & 14 & 11 & 11 & 42 & 39 \\
\hline Single parent & 6 & 7 & 4 & 5 & 7 & 5 & 3 & 10 & 21 & 23 \\
\hline
\end{tabular}

*Mother's age not always recorded. 
studies, ${ }^{67}$ the first child in a young family is more likely to be abused, especially under the age of 3 .

\section{Discussion}

The fourfold increase in the incidence of proved child abuse in South Birmingham during the past decade is partly associated with increasing public awareness and reporting, and it has occurred when the total population of children was falling. This may indicate a worrying increase in child abuse that may get even worse as the birth rate increases. Unemployment within the area increased by $50 \%$ between 1981 and 1986. There was a disproportionately high rate of households with single parents, and the illegitimate birth rate was $27 \%$ of all births. High migration increases the difficulty of maintaining contact with families at risk and each new family takes time to identify and understand. Even without the problems of child abuse or neglect, such social deprivation places a considerable burden on staff working in child health.

The workload associated with the follow up of cases of proved abuse has led to some of our health visitors now spending up to $25 \%$ of their working week on cases of child abuse. On average, $10 \%$ of our health visitors' time is spent on investigating or monitoring such cases. This type of work is unpleasant and may be changing health visitors into social policemen/women. The relative decrease in the number of serious injuries (table 2) may reflect at least partially the success of the policy of increased support for high risk families, especially as a consequence of the 1980 Children and Young Persons Act. A similar fall in cases of serious abuse was reported from South Glamorgan between 1972 and $1982^{8}$ which contrasts with the experience in the north west of the United States of America, where there was an increase in serious injuries during the early 1970s. ${ }^{9}$ A report from Bradford, however, was pessimistic about the effectiveness of the current policy of intervention. ${ }^{10}$

Successful prevention requires recognition of the circumstances which lead families to deprivation and abuse. There are some who believe that the welfare state has created a subclass that can only better its lot by sinking further in order to obtain additional provision. ${ }^{11}$ Certainly the quickest way to get a child into some municipal nurseries is by holding an abuse case conference. Alternative methods of rectifying poor parent care are urgently required. Reproduction is our main biological function and it is therefore of concern that many educational authorities assume that the skills of parenthood are instinctive and do not need to be taught. More and better use could also be made of contact with medical and other professional people when there is not a crisis. During the antenatal period mothers are particularly receptive to advice about child care; perhaps antenatal classes should devote more time to teaching them about caring for the baby and less to the actual conduct of the confinement.

It may also be necessary to reconsider whether the accepted (sociological) model of child abuse is correct. An alternative biological explanation has statistical support. ${ }^{12}$ Lower animals are more kindly disposed to their genetic kin than towards others of their species, and it is similar with humans. The ratio of unrelated to related assailants in murder cases is 10:1. Children are most often abused or killed by a non-blood relative, infanticide is rare, and not dependent on the mother's marital state, but is inversely related to her age. ${ }^{12}$ Older mothers may be restrained from abusing their children because of their decreasing fertility. Infanticide and child abuse may be a primeval response to unpropitious circumstances. Lactating hamsters eat their young if the nest is disturbed.

If this biological model is correct then there are two immediate consequences. Firstly, the environment in which young unsupported families are housed must assume a higher priority but, so that this is not misused, such provision might include removal of some parental rights. Secondly, those children who cannot be discouraged from indulging in sexual experience must have ready access to contraception until such time as their emotional and biological development is in step.

In no condition have the medical and social models shown more limitation than in the treatment of abused children. Those who are least able to protect themselves continue to suffer. 'Even without damage from trauma, even without the associated effects of poverty, deprivation, undernutrition or neglect, the child cannot be expected to thrive in a house in which fear of bodily harm is an unrelenting spectre'. ${ }^{13}$ These children may one day become parents themselves. It is of great concern that this cycle of deprivation and abuse appears to be self perpetuating and that mechanisms for this perpetuation appear to be enshrined within our current statutes of child care.

Increasing detection and support of abused children cannot be done with current staffing levels and budget limits unless other aspects of child care are ignored.

\footnotetext{
References

1 Bakan D. Slaughter of the innocents. San Francisco: Jessey-Bass Inc. 1971 .

2 Select Committee on Violence in the Family. Violence to the children. First report, session 1976-7. London: HMSO, 1977.
} 
${ }^{3}$ Kempe CH, Silverman FN, Stecle RF, Droegemueller W, Silver $H$. The battered child syndrome. JAMA 1962;181:17-24.

4 Department of Health and Social Security. Child Abuse: working together. A guide to arrangements for inter-agency cooperation for the protection of children. London: HMSO, 1986.

5 Wild NJ. Sexual abuse of children in Leeds. $\mathrm{Br}$ Med $\mathrm{J}$ 1986;292:1113-6.

${ }^{6}$ Smith SM, Hanson R. 134 battered children: a medical and psychological study. $\mathrm{Br}$ Med $J$ 1974;iii:666-70.

7 Taitz LS, King JM, Nicholson J, Kessel M. Unemployment and child abuse. $\mathrm{Br}$ Med $J$ 1987;294:1074-5.

${ }^{8}$ Jenkins J, Gray OP. Changing pattern of child abuse. Br Med J 1983;287:1767-9.

9 Bergman AB, Carsen RM, Bueller BA. Changing spectrum of serious child abuse. Pediatrics 1986;77:113-6.
${ }^{10}$ Lealman GT, Haigh D, Phillips JM, Stone J, Ord-Smith J. Prediction and prevention of child abuse-an empty hope. Lancet 1983;ii:1423-4.

"Graham D, Clarke P. The new enlightenment. London: Macmillan 1986.

12 Daly M, Wilson M. Homicide and kinship. American Anthropology 1982;84:372-8.

13 Martin HP. The development of abused children. Adv Paediatr 1974;21:25-73.

Correspondence to Dr A Sharma, Springfield Centre, Raddlebarn Road, Selly Oak, Birmingham B29 6JB.

Received 27 July 1987 